International Research Journal of Management, IT \& Social Sciences
Available online at https://sloap.org/journals/index.php/irjmis/
Vol. 9 No. 2, March 2022, pages: 244-253
ISSN: 2395-7492
https://doi.org/10.21744/irjmis.v9n2.2053

\title{
Company Performance Analysis and Tax Aggressiveness
}

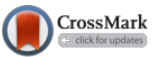

\author{
Ruhiyat Taufik ${ }^{a}$ \\ Hani Hasanah $^{\text {b }}$ \\ Sri Lestari ${ }^{c}$ \\ Nela Dharmayanti ${ }^{\mathrm{d}}$ \\ Resty Sriharyanti ${ }^{\mathrm{e}}$
}

Article history:

Submitted: 09 November 2021

Revised: 18 December 2021

Accepted: 27 January 2022

\section{Keywords:}

aggressiveness; analysis aggressiveness; company performance; tax aggressiveness; variable intensity;

Corresponding author:

Ruhiyat Taufik,

Sheikh Yusuf Islamic University, Tangerang, Indonesia.

Email address: rtaufik@unis.ac.id

\begin{abstract}
This study aims to determine the effect of return on assets, firm size, leverage and intensity of fixed assets, both partially and simultaneously on tax aggressiveness in LQ 45 companies listed on the Indonesia Stock Exchange in 2015-2018. The analytical method used is panel data regression analysis. The sample selection technique used was purposive sampling and obtained $35 \mathrm{LQ}$ 45 companies with a research period of four years, 2015-2018, so that 140 units of observation were obtained. The results showed that the variable return on assets and the variable intensity of fixed assets partially had a significant effect on tax aggressiveness. Meanwhile, company size and leverage partially have no effect on tax aggressiveness.
\end{abstract}

International research journal of management, IT and social sciences (C) 2022. This is an open access article under the CC BY-NC-ND license (https://creativecommons.org/licenses/by-nc-nd/4.0/).

\footnotetext{
Sheikh Yusuf Islamic University, Tangerang, Indonesia

Sheikh Yusuf Islamic University, Tangerang, Indonesia

Sheikh Yusuf Islamic University, Tangerang, Indonesia

Sheikh Yusuf Islamic University, Tangerang, Indonesia

Sheikh Yusuf Islamic University, Tangerang, Indonesia 


\section{Introduction}

One of the biggest sources of state revenue is taxes. Every taxpayer is required to participate so that the rate of growth and implementation of national development can run well for the progress and welfare of the State. Analysis of Financial Statements. Raja Grafindo Persada: Jakarta. However, from the company's point of view, taxes are a burden for companies that can reduce a company's net profit, so many companies are trying to reduce taxes legally or illegally so that they are able to achieve the profit targets that have been set. Taxes are the largest source of state revenue. Therefore, the government encourages companies and private individuals to pay taxes with various socializations. In practice, there are still many companies and individuals who have not carried out their tax obligations (Taufik \& Bastian, 2018). Many companies and individuals are also trying to minimize their tax payments through tax aggressiveness activities. If done properly, tax aggressiveness can provide significant benefits, especially for corporate taxpayers (Lanis \& Richardson, 2012; Richardson et al., 2013).

Taxes according to Law Number 28 of 2007 concerning General Provisions on Tax Procedures article 1 paragraph 1 are, "compulsory contributions to the state owed by individuals or entities that are coercive under the law without receiving direct compensation and are used for the state's purposes for as much as possible. the great prosperity of the people". In Law No. 36 of 2008 article 2 paragraph 1, it is explained that a personal tax subject is a tax subject who resides in Indonesia or does not reside in Indonesia (Prameswari, 2017). Meanwhile, what is meant by corporate tax subject is a group of people and/or capital which is a unit whether doing business or not doing business which includes a limited liability company (PT), limited liability company (CV), other companies, state-owned enterprises (BUMN) or regional-owned enterprises (BUMD) with any name and form, joint venture firms, cooperatives, pension funds, partnerships, associations, foundations, mass organizations, socio-political organizations, or other organizations, institutions, permanent establishments and other forms of entities (Richardson et al., 2015; Whait et al., 2018).

Tax aggressiveness can arise because of differences in interests between taxpayers and the government. The government needs funds to finance the implementation of government activities, most of which income comes from taxes. ROA (Return on Assets) is one of the ratios that can describe the company's profitability. The higher the profitability of the company, the company will receive a high tax burden. Company size shows the company's ability to return to its tax decisions. The size of the company shows the stability and ability of the company to carry out its economic activities. Leverage is the use of a source of funds that has a fixed rate of return with the hope of providing greater profits than the fixed costs so that it will increase returns for shareholders. The intensity of ownership of fixed assets can affect the company's tax payments (Prapitasari \& Safrida, 2019). The intensity of the company's fixed assets describes the company's investment in the company's fixed assets (Morris \& Sexton, 1996; Avlonitis \& Gounaris, 1997).

\section{Methods}

The method used is a quantitative method (Luke \& Zulaikha, 2016). The population used in this study were LQ 45 companies listed on the Indonesia Stock Exchange (IDX) in 2015-2018 using a purposive sampling technique with the following criteria:

1. LQ 45 companies listed on the IDX during 2015-2018,

2. Companies that present financial statements in rupiah currency

3. Companies that do not experience losses during the observation period

4. Companies that present financial statements as of December 31 during the observation period

5. Companies that have complete data related to the variables used.

\section{Dependent variable}

The dependent variable in this study is tax aggressiveness. Tax aggressiveness is the actions taken by the company to reduce its tax obligations. Tax aggressiveness is proxied into Effective Tax Rates (ETR). The lower the ETR value, the higher the company's tendency to tax aggressiveness (Hidayat, 2016). The ETR calculation formula (Luke \& Zulaikha, 2016).

Taufik, R., Hasanah, H., Lestari, S., Dharmayanti, N., \& Sriharyanti, R. (2022). Company performance analysis and tax aggressiveness. International Research Journal of Management, IT and Social Sciences, 9(2), 244-253. 
Independent variable

Return on Assets (ROA) is the ratio of net income to total assets.

Company size

Company size is a measure that is grouped based on the size of the company. Company size is proxied by Ln total assets. The use of natural $\log (\mathrm{Ln})$ is intended to reduce excessive fluctuations in data without changing the proportion of the actual original value (Nurfadilah, 2016). From the explanation above, the formula for company size is as follows (Prapitasari \& Safrida, 2019):

\section{Leverage}

Leverage ratio is a ratio used to measure how much debt the company must bear in order to fulfill assets. (Purwanto (2016) states that leverage (DER) has a significant positive effect on tax aggressiveness. From the explanation above, it measures the company's ability to generate profits.

\section{Fixed asset intensity}

The intensity of fixed assets is an indicator that can provide an overview of the amount of investment owned by the company in the form of fixed assets. According to Purwanti \& Sugiyarti Listya (2017), asset intensity is obtained from comparing the total fixed assets with the total assets in the company. The intensity of fixed assets is calculated by the following formula.

\section{Results and Discussions}

\section{Descriptive analysis}

Descriptive statistics are carried out with the aim of describing or providing a general picture of the object under study through sample or population data according to the actual situation, then processed and presented in tabular form to make it easier to understand (Aminah et al., 2017). The descriptive analysis presented in this study consists of the mean, median, minimum, maximum, and standard deviation obtained from each sample of LQ 45 companies listed on the Indonesia Stock Exchange in the 2015-2018 period as many as 35 companies so as to obtain observational data of 140 data. The results of the calculation and descriptive statistical tests are presented in table 1 below:

Table 1

Descriptive analysis

\begin{tabular}{lcccc}
\hline \multicolumn{2}{l}{ Sample: 20152018} & & & \\
& ETR & ROA & SIZE & IAT \\
\hline Mean & 0.260500 & 10.05707 & 17.80043 & 24.99236 \\
Median & 0.250000 & 6.640000 & 17.56000 & 21.37500 \\
Maximum & 2.150000 & 46.66000 & 20.98000 & 70.45000 \\
Minimum & 0.000000 & 0.230000 & 15.17000 & 0.000000 \\
Std. Dev. & 0.193830 & 9.800928 & 1.389477 & 19.84958 \\
Skewness & 6.837516 & 1.865233 & 0.577134 & 0.627561 \\
Kurtosis & 66.32152 & 6.148719 & 2.771177 & 2.429348 \\
Jarque-Bera & 24480.29 & 139.0130 & 8.077395 & 11.08904 \\
Probability & 0.000000 & 0.000000 & 0.017620 & 0.003909 \\
Sum & 36.47000 & 1407.990 & 2492.060 & 3498.930 \\
Sum Sq. Dev. & 5.222265 & 13352.09 & 268.3598 & 54766.83 \\
Observations & 140 & 140 & 140 & 140 \\
\hline
\end{tabular}


Panel data regression analysis

Linear regression analysis of panel data in this study used the random effects model method. The selection of the random effects model method as a panel data analysis method in this study was previously tested through the Chow test, Hausman test and Lagrange multiplier test first, so that finally the random effects model method was the most appropriate for testing panel data in this study.

Table 2

Panel data regression test results with random effects model method

Dependent Variable: LNETR

Method: Panel EGLS (Cross-section random effects)

Date: 05/17/20 Time: 16:19

Sample (adjusted): 20162018

Periods included: 3

Cross-sections included: 35

Total panel (balanced) observations: 105

Swamy and Arora estimator of componentvariances

\begin{tabular}{ccccc}
\hline Variable & Coefficient & Std. Error & t- Statistic & Prob. \\
\hline C & -39984.11 & 32911.93 & -1.21488 & 0.2273 \\
LNETR(-1) & 0.6734 & 0.065190 & 0.33099 & 0.0000 \\
LNROA & -0.015638 & 0.006247 & -2.503266 & 0.0139 \\
LNSIZE & -0.004591 & 0.008643 & -0.531211 & 0.5965 \\
LNDER & -0.000163 & 0.010584 & -0.015396 & 0.9877 \\
LNIAT & 0.012924 & 0.004284 & 3.016726 & 0.0032
\end{tabular}

Effects Specification

Cross-section random

S.D.

Rho

Idiosyncratic random

$\begin{array}{ll}0.000000 & 0.0000 \\ 48577.66 & 1.0000\end{array}$

Weighted Statistics

R-squared $0.431293 \quad$ Mean $\quad-146458.8$

Table 3

Dependent var

\begin{tabular}{|c|c|c|c|}
\hline Adjusted R-squared & 0.402571 & S.D. dependentvar & 80645.34 \\
\hline S.E. ofregression & 62333.66 & Sum squaredresid & $3.85 \mathrm{E}+11$ \\
\hline F-statistic & 15.01583 & Durbin-Watsonstat & 1.707786 \\
\hline $\operatorname{Prob}(\mathrm{F}-$ statistic $)$ & 0.000000 & & \\
\hline \multicolumn{4}{|c|}{ Unweighted Statistics } \\
\hline$\overline{\mathrm{R} \text {-squared }}$ & 0.431293 & Mean dependent var & -146458.8 \\
\hline Sum squaredresid & $3.85 \mathrm{E}+11$ & Durbin- Watson stat & 1.707786 \\
\hline
\end{tabular}

Taufik, R., Hasanah, H., Lestari, S., Dharmayanti, N., \& Sriharyanti, R. (2022). Company performance analysis and tax aggressiveness. International Research Journal of Management, IT and Social Sciences, 9(2), 244-253. 
Results of hypothesis testing with random effects model method

Table 4

Dependent variable: LNETR

\begin{tabular}{|c|c|c|c|c|}
\hline \multicolumn{5}{|c|}{ Method: Panel EGLS (Cross-section random effects) } \\
\hline \multicolumn{5}{|c|}{ Date: 05/17/20 Time: $16: 19$} \\
\hline \multicolumn{5}{|c|}{ Sample (adjusted): 20162018} \\
\hline \multicolumn{5}{|c|}{ Periods included: 3} \\
\hline \multicolumn{5}{|c|}{ Cross-sections included: 35} \\
\hline \multicolumn{5}{|c|}{ Total panel (balanced) observations: 105} \\
\hline \multicolumn{5}{|c|}{ Swamy and Arora estimator of componentvariances } \\
\hline Variable & Coefficient & Std. Error & $\mathrm{t}-\mathrm{St}$ & Prob. \\
\hline $\mathrm{C}$ & -39984.11 & 32911.93 & -1.2 & 0.2273 \\
\hline $\operatorname{LNETR}(-1)$ & 0.673480 & 0.065190 & 10.3 & 0.0000 \\
\hline LNROA & -0.015638 & 0.006247 & -2.5 & 0.0139 \\
\hline LNSIZE & -0.004591 & 0.008643 & -0.5 & 0.5965 \\
\hline LNDER & -0.000163 & 0.010584 & -0.0 & 0.9877 \\
\hline LNIAT & 0.012924 & 0.004284 & 3.01 & 0.0032 \\
\hline \multicolumn{5}{|c|}{ Effects Specification } \\
\hline \multicolumn{5}{|c|}{ S.D. } \\
\hline \multicolumn{2}{|l|}{ Cross-section random } & 0.000000 & \multicolumn{2}{|c|}{0.0000} \\
\hline \multicolumn{2}{|l|}{ Idiosyncratic random } & 48577.66 & \multicolumn{2}{|c|}{1.0000} \\
\hline \multicolumn{5}{|c|}{ Weighted Statistics } \\
\hline R-squared & 0.431293 & \multicolumn{2}{|c|}{ Mean dependent var } & -146458.8 \\
\hline Adjusted & 0.402571 & \multicolumn{2}{|c|}{ S.D.dependent var } & 80645.34 \\
\hline \multicolumn{5}{|l|}{ R-squared } \\
\hline $\begin{array}{l}\text { S.E.of } \\
\text { regression }\end{array}$ & 62333.66 & \multicolumn{2}{|c|}{$\begin{array}{c}\text { Sumsquare } \\
\text { dresid }\end{array}$} & $3.85 \mathrm{E}+11$ \\
\hline F-statistic & 15.01583 & \multicolumn{2}{|c|}{$\begin{array}{c}\text { Durbin Watson } \\
\text { stat }\end{array}$} & 1.707786 \\
\hline Prob(F- statistic) & 0.000000 & & & \\
\hline \multicolumn{5}{|c|}{ UnweightedStatistics } \\
\hline R-squared & 0.431293 & Mean deper & t var & -146458.8 \\
\hline $\begin{array}{l}\text { Sum square } \\
\text { dresid }\end{array}$ & $3.85 \mathrm{E}+11$ & Durbin-Wa & istat & 1.707786 \\
\hline
\end{tabular}

Based on table 2, the panel data regression equation in this study can be formulated as follows:

$$
\begin{gathered}
\text { Yit }=\beta 0+\beta 1 X 1 \text { it }+\beta 2 \text { X2it }+\beta 3 \text { X3it }+\beta 4 \text { X4it }+ \text { Uit } \\
\text { LnETR }=-39984.11-0.015638 \text { LnROA }-0.004591 \text { LnSIZE }-0.000163 \text { LnDER + 0.012924LnIAT }
\end{gathered}
$$

The panel data regression equation above has a constant value of -39984.11 this number indicates that if the independent variables in the regression are Return on Assets (ROA), Leverage company size, Fixed Asset Intensity is 0, then Tax Aggressiveness in LQ 45 Company is -39984.11 unit (Hidayat, 2016). The regression coefficient on the Return on Asset (ROA) (X1) variable is 0.015638 . This figure shows that every time there is an increase in Return on Assets (ROA) by one unit with the assumption that other variables are worth 1, the Tax Aggressiveness of LQ 45 Company will increase by 0.015638 . The regression coefficient on the Firm Size variable (X2) is 0.004591. This figure shows that every time there is an increase in the size of the company by one unit with the assumption that the other variable is 1, the tax aggressiveness of the LQ 45 company will increase by 0.004591 (Lanis \& Richardson, 2011; Laguir et al., 2015). 


\section{Coefficient of determination}

Based on the results of panel data regression analysis using the random effects model in table 3, the Adjusted R-square value is obtained at 0.402571 or $40.25 \%$, which means that the independent variables in this study consist of Return On Assets (ROA), Firm Size, Leverage, Intensity of Fixed Assets can explain the dependent variable, namely the aggressiveness of corporate tax by $40.20 \%$.

\section{Simultaneous test results}

The results of the $\mathrm{F}$ test hypothesis test (simultaneous test) with the random effects model method, for Prob (Fstatistics) obtained a value of -value $0.000000<$ alpha 0.05 then reject $\mathrm{H} 0$ which means return on assets (ROA), firm size, leverage, asset intensity remain simultaneously against tax aggressiveness (Pérez-Latorre et al., 2010; Warnemuende et al., 2007).

\section{Partial test results}

This test uses the following significance level. If the probability 0.05 then $\mathrm{H} 0$ is rejected, there is an influence between the independent variables partially on the dependent variable (Budianti et al., 2018). Meanwhile, if the probability 0.05 then $\mathrm{HO}$ is accepted, there is no influence between the independent variables partially on the dependent variable. Based on the results of panel data regression analysis using the random effects model in table 3 , the probability value of the Return on Asset (ROA) variable is 0.0139. This value indicates that for return on assets (ROA) -value $0.0139<$ alpha 0.05 , then reject $\mathrm{H} 0$ which means that return on assets (ROA) has a significant effect on tax aggressiveness (Harahap et al., 2021; Taufik, 2022).

The probability value of the company size variable using the random effects model method, for company size value $0.5965>$ alpha 0.05 , then accept $\mathrm{H} 0$ which means that company size has no effect on tax aggressiveness. The probability value of the Leverage variable using the random effects model method, for leverage -value $0.9877>$ alpha 0.05 , then accept $\mathrm{H} 0$ which means that leverage has no effect on tax aggressiveness. The probability value of the fixed asset intensity variable using the random effects model method, for the intensity of fixed assets -value $0.0032<$ alpha 0.05 , then accept $\mathrm{H} 0$ which means that the intensity of fixed assets has an effect on tax aggressiveness.

\section{The effect of return on assets (ROA) on tax aggressiveness}

The results of the partial test between the Return On Assets (ROA) variable on tax aggressiveness show a value of value 0.0139 < alpha 0.05 then accept $\mathrm{H} 1$ which means there is sufficient evidence to state that there is a significant effect of return on assets (ROA) on tax aggressiveness in LQ 45 companies that listed on the Indonesia Stock Exchange in 2015-2018. The results of this study are also in accordance with the research conducted by Aminah et al. (2017), with the title the influence of company size, fixed asset intensity, leverage, profitability, and political connection to tax avoidance. The result showed that the profitability have influences to tax avoidance. On the other hand, this research is different from the research conducted by Budianti et al. (2018), with the title the effect of return on assets (ROA), leverage (DER), independent commissioners and company size on tax aggressiveness. The results showed that partially Return on Assets (ROA) had no effect on tax aggressiveness (Nugraha \& Meiranto, 2015; Suwardika \& Mustanda, 2017).

\section{The effect of firm size on tax aggressiveness}

The results of the partial test between company size variables on tax aggressiveness show -value $0.5965>$ alpha 0.05 then accept $\mathrm{H} 0$ which means there is not enough evidence to state that there is a significant effect of company size on tax aggressiveness in LQ 45 companies listed on the Indonesia Stock Exchange in 2015-2018. The results of this study are also in accordance with the research conducted by Dharma \& Ardiana (2016), with the title the effect of leverage, fixed asset intensity, firm size, and political connection to tax avoidance. The results of the analysis show that firm size has a positive effect on tax avoidance. This means that the higher the size of the company, the higher the tax avoidance action. On the other hand, this research is different from the research conducted by Susanto et al. (2018),

Taufik, R., Hasanah, H., Lestari, S., Dharmayanti, N., \& Sriharyanti, R. (2022). Company performance analysis and tax aggressiveness. International Research Journal of Management, IT and Social Sciences, 9(2), 244-253. 
with the title factors that affect tax aggressiveness. The results showed that the company's characteristics as proxied by company size had no effect on tax aggressiveness.

\section{The effect of leverage on tax aggressiveness}

The results of partial 3 tests between the leverage variable on tax aggressiveness show the value -value $0.9877>$ alpha 0.05 then accept $\mathrm{H} 0$ which means that there is not enough evidence to state that there is a significant effect of leverage on tax aggressiveness in LQ 45 companies listed on the Indonesia Stock Exchange in 2015 -2018. The results of this study are also in accordance with research conducted by Prapitasari \& Safrida (2019), with the title The effect of profitability, leverage, firm size, political connection and fixed asset intensity on tax avoidance (empirical study on mining companies listed in Indonesia stock exchange 2015). -2017). The results of this research shows that leverage has a negative influence on tax avoidance. On the other hand, this research is different from the research conducted by Ann \& Manurung (2019), with the title the effect of independent commissioners, leverage, inventory intensity, fixed asset intensity and firm size on tax aggressiveness in corporate taxpayers (empirical study on manufacturing companies listed on the Indonesia Stock Exchange). Period 2014-2016). The results showed that leverage had an effect on tax aggressiveness.

\section{Effect of fixed assets intensity on tax aggressiveness}

The results of the partial test between the variable intensity of fixed assets on tax aggressiveness show a value of value 0.0032 < alpha 0.05 then accept $\mathrm{H} 1$ which means there is sufficient evidence to state that there is a significant effect of the intensity of fixed assets on tax aggressiveness in LQ 45 companies listed on the Indonesia Stock Exchange in 2015-2018. The results of this study are also appropriate with research conducted by Adisamartha \& Noviari (2015), with the title the effect of liquidity, leverage, inventory intensity and fixed asset intensity on the level of aggressiveness of corporate taxpayers. The results obtained are the inventory intensity factor has a positive and significant effect on the level of tax aggressiveness.

\section{Effect of return on assets (ROA), company size, leverage, intensity of fixed assets simultaneously on tax aggressiveness}

The results of simultaneous testing of return on assets (ROA) variables, firm size, leverage, and the intensity of fixed assets simultaneously on tax aggressiveness show a value of -value $0.000<$ alpha 0.05 , so accept $\mathrm{H} 1$ which means there is sufficient evidence to state that there is a significant effect of return on assets. (ROA) (Hidayat, 2016). Company size, leverage, and fixed asset intensity simultaneously on tax aggressiveness in LQ 45 companies listed on the Indonesia Stock Exchange in 2015-2018. The contribution of return on assets (ROA), firm size, leverage, intensity of fixed assets simultaneously to tax aggressiveness is $40.2571 \%$ and the remaining $59.7429 \%$ is influenced by other variables not examined.

The results of this study are also in accordance with research conducted (Budianti et al., 2018). With the title the effect of return on assets (ROA), leverage (DER), independent commissioners and company size on tax aggressiveness. Simultaneous test results show that the variables of return on assets (ROA), leverage (DER), independent commissioners, and company size affect tax aggressiveness. Furthermore, the results of this study are in accordance with the research conducted by Purwanti \& Sugiyarti Listya (2017), with the title the effect of the intensity of fixed assets, in sales growth and political connections to tax avoidance. The results of this research show that simultaneously the intensity of fixed assets, sales growth and political connections have a significant effect on tax avoidance.

\section{Conclusion}

1. This study aims to determine the effect of Return On Asset (ROA), Firm Size (SIZE), Leverage, Fixed Asset Intensity on tax aggressiveness in LQ 45 companies listed on the Indonesia Stock Exchange (IDX) from 20152018. The number of samples in this study is that there are 140 companies within a period of 4 (four) years so that 35 research samples are obtained.

2. Based on hypothesis testing simultaneously all independent variables, namely Return On Assets (ROA), Firm Size (SIZE), Leverage, and Fixed Asset Intensity simultaneously have a significant effect on the Tax Aggressiveness of LQ 45 companies listed on the Indonesia Stock Exchange (IDX) for the 2015-2015 period. 
2018. Meanwhile, based on partial hypothesis testing, company size (SIZE) has no effect on tax aggressiveness, but leverage has a negative effect on tax aggressiveness of mining sector companies listed on the Indonesia Stock Exchange (IDX) for the 2015-2018 period.

Conflict of interest statement

The authors declared that they have no competing interests.

Statement of authorship

The authors have a responsibility for the conception and design of the study. The authors have approved the final article.

Acknowledgments

We are grateful to two anonymous reviewers for their valuable comments on the earlier version of this paper.

Taufik, R., Hasanah, H., Lestari, S., Dharmayanti, N., \& Sriharyanti, R. (2022). Company performance analysis and tax aggressiveness. International Research Journal of Management, IT and Social Sciences, 9(2), 244-253.

https://doi.org/10.21744/irjmis.v9n2.2053 


\section{References}

Adisamartha, I. B. P. F., \& Noviari, N. (2015). The Effect of Liquidity, Leverage, Inventory Intensity and Intensity of Fixed Assets on the Aggressiveness Level of Corporate Taxpayers. E-Jurnal Akuntansi Universitas Udayana, 13(3), 973-1000.

Aminah, A., Chairina, C., \& Sari, Y. Y. (2018). The influence of company size, fixed asset intensity, leverage, profitability, and political connection to tax avoidance. AFEBI Accounting Review, 2(02), 107-120.

Ann, S., \& Manurung, A. H. (2019). The influence of liquidity, profitability, intensity inventory, related party debt, and company size to aggressive tax rate. Archives of Business Research, 7(3), 105-115.

Avlonitis, G. J., \& Gounaris, S. P. (1997). Marketing orientation and company performance: industrial vs. consumer goods companies. Industrial Marketing Management, 26(5), 385-402. https://doi.org/10.1016/S00198501(96)00121-6

Budianti, I., Nazar, M. R., \& Kurnia, K. (2018). Pengaruh Return On Asset (roa), Leverge (der), Komisaris Independen Dan Ukuran Perusahaan Terhadap Agresivitas Pajak (studi Pada Perusahaan Bumn Yang Terdaftar Di Bursa Efek Indonesia Periode 2012-2016). eProceedings of Management, 5(2).

Dharma, I. M. S., \& Ardiana, P. A. (2016). Pengaruh leverage, intensitas aset tetap, ukuran perusahaan, dan koneksi politik terhadap tax avoidance. E-Jurnal Akuntansi Universitas Udayana, 15(1), 584-613.

Harahap, R. M., Mustaruddin, M., \& Rustam, R. (2021). The effect of efficiency, market power, debt, and risk on company performance and their impact on dividend policy on the manufacturing sector in the Indonesia stock exchange. International Journal of Business, Economics \& Management, 4(4), 477-486. https://doi.org/10.21744/ijbem.v4n4.1804

Hidayat, K. (2016). Influence of Corporate Social Responsibility at Tax Incentives Tax Aggressiveness as moderating (Study on mining companies listed on the Stock Exchange). JIAFE (Scientific Journal of Accounting Faculty of Economics), 2(2), 39-59.

Laguir, I., Staglianò, R., \& Elbaz, J. (2015). Does corporate social responsibility affect corporate tax aggressiveness?. Journal of cleaner production, 107, 662-675. https://doi.org/10.1016/j.jclepro.2015.05.059

Lanis, R., \& Richardson, G. (2011). The effect of board of director composition on corporate tax aggressiveness. Journal of accounting and Public Policy, 30(1), 50-70. https://doi.org/10.1016/j.jaccpubpol.2010.09.003

Lanis, R., \& Richardson, G. (2012). Corporate social responsibility and tax aggressiveness: An empirical analysis. Journal of Accounting and Public Policy, 31(1), 86-108. https://doi.org/10.1016/j.jaccpubpol.2011.10.006

Luke, L., \& Zulaikha, Z. (2016). Analisis Faktor Yang Mempengaruhi Agresivitas Pajak (Studi Empiris Pada Perusahaan Manufaktur Yang Terdaftar di Bursa Efek Indonesia Pada Tahun 2012-2014). Jurnal Akuntansi dan Auditing, 13(1), 80-96.

Morris, M. H., \& Sexton, D. L. (1996). The concept of entrepreneurial intensity: Implications for company performance. Journal of Business Research, 36(1), 5-13. https://doi.org/10.1016/0148-2963(95)00158-1

Nugraha, N. B., \& Meiranto, W. (2015). Pengaruh Corporate Social Responsibility, Ukuran Perusahaan, Profitabilitas, Leverage dan Capital Intensity Terhadap Agresivitas Pajak (Studi Empiris pada Perusahaan NonKeuangan yang Terdaftar di BEI Selama Periode 2012-2013) (Doctoral dissertation, Fakultas Ekonomika dan Bisnis).

Nurfadillah, M. (2016). ANALISIS PENGARUH EARNING PER SHARE, DEBT TO EQUITY RATIO DAN RETURN ON EQUITY TERHADAP HARGA SAHAM PT UNILEVER INDONESIA Tbk. Jurnal Manajemen dan Akuntansi, 12(1).

Pérez-Latorre, F. J., de Castro, L., \& Delgado, A. (2010). A comparison of two variable intensity rainfall simulators for runoff studies. Soil and Tillage Research, 107(1), 11-16. https://doi.org/10.1016/j.still.2009.12.009

Prameswari, F. (2017). Pengaruh Ukuran Perusahaan Terhadap Agresivitas Pajak Dengan Corporate Social Responsibility (CSR) Sebagai Varaibel Moderasi. E-Journal Akuntansi" EQUITY", 3(4).

Prapitasari, A., \& Safrida, L. (2019). The effect of profitability, leverage, firm size, political connection and fixed asset intensity on tax avoidance (empirical study on mining companies listed in indonesia stock exchange 20152017). ACCRUALS (Accounting Research Journal of Sutaatmadja), 3(2), 247-258.

Purwanti, S. M., \& Sugiyarti Listya. (2017). Pengaruh Intensitas Aset Tetap, Pertumbuhan Penjualan, dan Koneksi Politik terhadap Tax Avoidance. Jurnal Riset Akuntansi dan Keuangan. Hal, 1625-1642. 
Purwanto, A. (2016). Pengaruh likuiditas, leverage, manajemen laba, dan kopensasi rugi fiskal terhadap agresivitas pajak perusahaan pada perusahaan pertanian dan pertambangan yang terdaftar di bursa efek indonesia periode 2011-2013. Riau University.

Richardson, G., Lanis, R., \& Taylor, G. (2015). Financial distress, outside directors and corporate tax aggressiveness spanning the global financial crisis: An empirical analysis. Journal of Banking \& Finance, 52, 112-129. https://doi.org/10.1016/j.jbankfin.2014.11.013

Richardson, G., Taylor, G., \& Lanis, R. (2013). The impact of board of director oversight characteristics on corporate tax aggressiveness: An empirical analysis. Journal of Accounting and Public Policy, 32(3), 68-88. https://doi.org/10.1016/j.jaccpubpol.2013.02.004

Susanto, L., Yanti, Y., \& Viriany, V. (2018). Faktor-faktor yang mempengaruhi agresivitas pajak. Jurnal Ekonomi, 23(1), 10-19.

Suwardika, I. N. A., \& Mustanda, I. K. (2017). Pengaruh leverage, ukuran perusahaan, pertumbuhan perusahaan, dan profitabilitas terhadap nilai perusahaan pada perusahaan properti (Doctoral dissertation, Udayana University).

Taufik, R. (2022). Financial structure and debt management on company profit performance. International Journal of Business, Economics \& Management, 5(1), 23-31. https://doi.org/10.21744/ijbem.v5n1.1856

Taufik, R., \& Bastian, A. F. (2018). The Effect of Ownership Structure and Dividend Policy in Determining Company Performance with Intellectual Capital as Intervening Variable (Study on Government Banks Listed on Stock Exchanges in Indonesia 2010-2015). International Journal of Advanced Scientific Research \& Development (IJASRD), 5(1), 13-24.

Warnemuende, E. A., Patterson, J. P., Smith, D. R., \& Huang, C. H. (2007). Effects of tilling no-till soil on losses of atrazine and glyphosate to runoff water under variable intensity simulated rainfall. Soil and Tillage Research, 95(12), 19-26. https://doi.org/10.1016/j.still.2006.09.001

Whait, R. B., Christ, K. L., Ortas, E., \& Burritt, R. L. (2018). What do we know about tax aggressiveness and corporate social responsibility? An integrative review. Journal of cleaner production, 204, 542-552. https://doi.org/10.1016/j.jclepro.2018.08.334

Taufik, R., Hasanah, H., Lestari, S., Dharmayanti, N., \& Sriharyanti, R. (2022). Company performance analysis and tax aggressiveness. International Research Journal of Management, IT and Social Sciences, 9(2), 244-253.

https://doi.org/10.21744/irjmis.v9n2.2053 